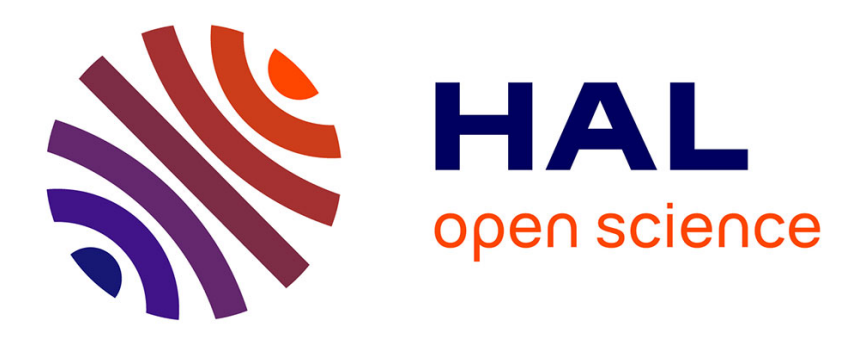

\title{
Institutional quality, conforming and evasive entrepreneurship
}

Julien Hanoteau, Virginie Vial

\section{To cite this version:}

Julien Hanoteau, Virginie Vial. Institutional quality, conforming and evasive entrepreneurship. Eurasian Business Review, 2020, 10 (1), pp.97-121. 10.1007/s40821-020-00151-z . hal-02511782

\section{HAL Id: hal-02511782 \\ https://hal-amu.archives-ouvertes.fr/hal-02511782}

Submitted on 20 May 2020

HAL is a multi-disciplinary open access archive for the deposit and dissemination of scientific research documents, whether they are published or not. The documents may come from teaching and research institutions in France or abroad, or from public or private research centers.
L'archive ouverte pluridisciplinaire HAL, est destinée au dépôt et à la diffusion de documents scientifiques de niveau recherche, publiés ou non, émanant des établissements d'enseignement et de recherche français ou étrangers, des laboratoires publics ou privés. 


\title{
Institutional quality, conforming and evasive entrepreneurship
}

\author{
Julien Hanoteau* \\ KEDGE Business School, CEO CSR, Marseille, FRANCE \\ \& \\ Aix-Marseille Univ., CNRS, EHESS, IRD, AMSE, Marseille, France \\ https://orcid.org/0000-0003-2951-9466 \\ Virginie Vial \\ KEDGE Business School, Marseille, France \\ $\&$ \\ Institut d'Asie Orientale (IAO, UMR CNRS 5062), ENS Lyon, France \\ https://orcid.org/0000-0002-6003-956X
}

*Contact author: Julien Hanoteau, julien.hanoteau@kedgebs.com

\begin{abstract}
In this article we unpack Baumol's (1990) theory of entrepreneurship's outcomes (productive, unproductive, and destructive) in a framework of failing institutions, considering that entrepreneurship is instead first characterized by two non-mutually exclusive types of behavior (conforming versus evasive). We hypothesize that the evasive activity (firm-level corruption) is undertaken as a second-best response to poor institutional quality, supporting the conforming activity. Using instrumental variable panel regression in the context of Indonesia, we evidence the mediating effect of bribing on the relation between local institutional quality and new business density, thus unveiling the real effect of institutional quality on entrepreneurship.
\end{abstract}

Key words: Entrepreneurship; Institutions; Corruption; Mediation; Indonesia

JEL classification: D73 · M13 · L26

Quote as: Hanoteau, J. and Vial, V., 2020. Institutional quality, conforming and evasive entrepreneurship. Eurasian Business Review, 10(1), pp.97-121.

\section{Introduction}

Baumol $(1990,2010)$ famously argues that institutions, because they shape the structure of relative incentives and rewards, also influence the distribution of entrepreneurs into several distinct categories. Although high-quality institutions encourage productive entrepreneurs who contribute positively to societal outcomes, poor institutions represent the breeding grounds for unproductive and destructive entrepreneurs who do not contribute or contribute negatively to societal outcomes by redistributing or even destroying existing value (e.g., lobbying, corruption, or criminality).

First, this approach (Baumol 1990; Murphy et al. 1991) establishes a direct causality among the quality of institutions, relative incentives, and the contribution of the enterprise to societal outcome. But 
doing so, it bypasses an essential element situated between the incentives provided by institutional quality and the outcome: entrepreneurial behavior, that is, ways to carry out entrepreneurial activities within or outside of institutional norms. Second, this classical framework distinguishes three categories of entrepreneurs rather than entrepreneurial activities, thereby excluding the possibility for an entrepreneur to simultaneously abide by some and depart from other institutional rules. The entrepreneur who carries out both types of activities however is widespread, especially in the context of poor institutional quality. This hybrid form combines activities responding to different relative incentives induced by a same level of institutional quality and falls outside Baumol's analysis. Building on the occupational choice approach, we propose a framework that enables to study the effect of institutional quality on entrepreneurship when this hybrid form is prevalent.

What differentiate categories of entrepreneurial activities is behavior vis à vis institutions: 'they can act to abide by, alter, or evade existing institutions' (Elert and Henrekson 2016: 97). The first category includes conforming entrepreneurial activities, which Webb et al. (2009) characterize as those activities seeking to comply with established formal and informal institutions, exploiting legal and legitimate means. The second category alters institutions by political means (also called institutional entrepreneurial activities) and is beyond the scope of this article. The third category, evasive entrepreneurial activities, evade the legal system, adapt to institutional deficiencies or bypass them altogether via activities in the market.

Conforming and evasive entrepreneurial activities can contribute positively or negatively to societal outcome (Davidsson and Wiklund 2001). Successful conforming entrepreneurial activities increase the societal outcome, through innovation for instance (Baumol 2010). Evasive activities such as criminal activities can destroy value, whereas lobbying and corruption can be the second-best solution for imperfect social and economic interactions (the first best being perfect institutions) (Douhan and Henrekson 2010), thereby providing a second-best yet positive contribution to societal outcome. Méon and Weill (2010) observe that corruption is less detrimental in countries where institutions are extremely deficient and can even be associated positively with efficiency. Belitski et al. (2016) show that in the presence of inefficient and/or excessive regulations, country-level corruption is associated with a relatively higher level of firm entry. Dreher and Gassebner (2013) put forward a "grease-the-wheel" effect of corruption on entrepreneurship. This argument suggests that in a context of institutional failures that materialize into trade and business impediments, bribing can provide some benefits to the firm if it helps to remove or mitigate these obstacles (Méon and Weill 2010).

This assumes an interaction between conforming and evasive entrepreneurial activities undertaken simultaneously by a single entity (Douhan and Henrekson 2010) and not necessarily performed by two separate and mutually exclusive categories of actors, as argued elsewhere (Murphy et al. 1991). For example, in developing economies plagued by failing institutions, firms often bribe, that is, engage in evasive entrepreneurial activities, in response to the complexity and unpredictability of regulations, unreliable bureaucrats, distrust, abnormal risks, and excessive transaction costs (Puffer et al. 2010). 
It is virtually impossible to disentangle the respective societal contributions of the two types of activities carried out by a single firm. It is however possible to isolate and examine the effects that institutional quality has on each entrepreneurial behavior category as well as on the interaction between these combined entrepreneurial behaviors. To unveil the effect of institutional quality on entrepreneurship, we distinguish its direct and indirect effects on conforming and evasive entrepreneurial behaviors that may coexist within a same enterprise or sector.

For a new venture, conforming behaviors are firstly to register and declare its existence, as it preconditions subsequent ones, such as accounting disclosure, tax declaration and payment, and compliance with all regulations. Evasive entrepreneurial activities, here corruption, can compensate for institutional failures, thereby supporting conforming entrepreneurial activities in a second-best perspective. This is our central hypothesis, which considers evasive activities as endogenous, because they are conditioned by the quality of institutions. This can be modeled as a positive mediating effect of evasive activities on the relation between failing institutions and conforming activities. We test our hypothesis in the context of Indonesia, which presents institutional features (e.g., administrative inefficiency, pervasive corruption, ethnic diversity, etc.) that are common to many developing countries (Miguel et al. 2005). Indonesia displays local institutions of low quality on average, but with large geographical variations within the country (Firman 2009). A similar institutional context prevails in other Southeast Asian economies, such as Vietnam (Tran 2019).

We test the mediation following the standard methods (Baron and Kenny 1986; Sobel 1982), using a two-stage least squares model (2SLS) for panel data that enables endogenizing evasive entrepreneurial activities measured by corruption. We evidence its mediating effect on the relation between the quality of formal and informal institutions and new business density. This reveals a two-track relationship between institutional quality and entrepreneurship, unveiled once we account for the mediating effect of evasive activities.

Our study goes beyond other research on corruption and entrepreneurship (Chowdhury and Audretsch 2014) and the grease-the-wheel effect on entrepreneurship (Dreher and Gassebner 2013; Zhou and Peng 2012), because we consider bribing behaviors as endogenous and mediating in the analysis. Other research usually treats corruption as an exogenous institutional context, and as a moderator, measuring it with country-level rankings and perception indicators, whereas our empirical approach is based on a firm-level measure of bribing. ${ }^{1}$ It contributes to the literature on institutions and entrepreneurship in Asian countries. For instance, Tran (2019) shows in the case of Vietnam, that a poor quality of local institutions (formal and informal) has detrimental effects on the performance of new ventures. This study considers corruption as endogenous, and as a component of the institutional context,

\footnotetext{
${ }^{1}$ Dutta and Sobel (2016) instrument endogenous corruption with its lagged values. We instead instrument corruption with institutional quality, thus accounting for a mediation and a causality between these two variables.
} 
endogenous as well. Our approach is different, although complementary, as we analyze bribing as the answer to failing institutions, justifying its treatment as a mediator.

The next section reviews the literature and derives a testable hypothesis. Section 3 depicts the Indonesian context and describes the data and empirical methodology. Our results are presented in Section 4, and Section 5 concludes and draws policy implications.

\section{Literature review and hypothesis development}

Institutions, either formal or informal, are essential determinants of entrepreneurship (Quatraro and Vivarelli 2014). As a set of rules, norms, values, and cultural meanings, they condition incentives and restrictions that shape the business environment and guide entrepreneurial behavior (North 1990).

Conforming entrepreneurial activities comply with established institutions (Webb et al. 2009). Formal institutions are regulative through laws and regulations that set and enforce the "rules of the game" (North 1990). They are also resource-allocative, in that they condition the access to society's scarce resources, for example, by regulating finance or by ensuring the provision of collective infrastructures and services (Kistruck et al. 2015). Legally registered firms that comply with legal rules also rely on informal institutions which comprise norms, values, and beliefs that condition social acceptability, establish local structures, and allocate resources to enable business activities (North 1990).

When questioned about the main local barriers to their activity, entrepreneurs and business persons put forward the poor quality of regulative and resource-allocative institutions, be they formal or informal (Sala-i-Martín and Schwab 2016). They notably quote inefficient bureaucracies, excessive tax rates and regulations, and a poor access to finance and infrastructures (transport, utilities). They also mention ethics, which — as a set of values and individual responsibilities — conditions trust in business.

Low institutional quality is detrimental to corporate risk-taking (Díez-Esteban et al. 2019), and distorts the allocation of entrepreneurial talent toward evasive entrepreneurial activities, such as lobbying or corruption. Corruption can take different forms. Grand corruption involves the political and economic elites of a country and results in the misallocation of government funds. It harms the economy (Mauro 1995) and represents an exogenous constraint for the large majority of firms. Petty corruption mostly refers to bribes paid by firms to obtain business permits and authorizations, avoid administrative burden, get access to public goods and services, and compensate for some local institutional failures. In a generalized poor institutional context, petty corruption concerns a far larger number of firms than grand corruption and creates additional costs for them (Tanzi 1998). These enterprises may choose to bear these costs (e.g., paying a bribe to obtain a business permit) as a better alternative to a worse situation (e.g., abandoning a start-up project). In this article, we focus on petty corruption, because it is directly linked to current and recurrent business activities (Vial and Hanoteau 2010).

Underdeveloped and inefficient regulative institutions create difficulties, uncertainty, and excessive costs that discourage potential business registration, investment in innovation, and other conforming entrepreneurial activities (Djankov et al. 2002). This raises an entrepreneur's likelihood of becoming 
involved in corruption (Tonoyan et al. 2010). For example, when obtaining business authorization requires going through numerous bureaucratic authorities and complying with long and complex procedures, paying bribes can increase public officials' incentives to serve the enterprises, thus affecting the speed and efficiency of business permits delivery (Vial Hanoteau 2010). This form of evasive activity may also enable an entrepreneur to navigate more swiftly through inefficient bureaucracies and spend less time with bureaucrats (Gohmann 2012).

Similarly, in front of excessive and arbitrary taxes, licenses, fees, and inspection costs levied by national and local authorities, entrepreneurs are prone to pay bribes to obtain tax and fee reductions (Park and Luo 2001), and this may offset the effect of excessive tax on firm entry (Belitski et al. 2016).

Entrepreneurs need good quality resource-allocative institutions such as access to infrastructures and financial capital, which are often underdeveloped and of uneven quality in developing countries, dampening entrepreneurship (Quatraro and Vivarelli 2014). In such contexts, bribing may enable firms to get better access to public infrastructures and services (Mauro 1995) and to formal finance (e.g., banking credit) (Tonoyan et al. 2010).

Informal finance is also important for business creation as a complement to and a substitute for formal finance, particularly in underdeveloped credit markets. However, when it is not enough to complement insufficient formal credit, or it is excessively costly, this motivates bribe payments in order to obtain better access to financial resources (Madestam 2014).

Trust in society, which is an established system of beliefs about the behaviors of others (Tonoyan et al. 2010), has extrinsic, instrumental value in helping to reduce the risks and transaction costs of relationships. When the government weakly enforces or fails to control legal contracts, and relational risks are thereby expensive to manage, firms use trust as a complement or substitute for handling these risks (Nooteboom 2007). Informal institutions, exemplified by social capital and trust, are thus important for new business development (Churchill 2017). However, when they are also missing, and there is a context of low trust, distrust, and generalized belief that others do not abide by the law, then firms have the incentive to bribe police, justice, or local government officers to compensate and manage relational risks. In such cases, bribes aim to establish a shared belief of reciprocity and increase the level of perceived trust (de Jong et al. 2012).

This suggests that, in a context of insufficient formal and informal institutional quality imposing additional barriers and costs on firms, evasive entrepreneurial activities will have a positive effect on entrepreneurship and its conforming activities (Douhan and Henrekson 2010). From an occupational choice model perspective, an agent chooses to become an entrepreneur with conforming activities despite failing institutions, because he or she will simultaneously decide to allocate part of his or her talent to evasive entrepreneurial activities. These activities compensate for the deficient institutional quality and hence ensure that conforming entrepreneurial activities will be possible or rewarding enough. Our central hypothesis is thus formulated as follows. 
Hypothesis: Evasive activities mediate the relation between institutional quality and conforming activities: Institutional quality is negatively related to evasive entrepreneurial activities, which in turn is positively related to conforming entrepreneurial activities.

\section{Data and methodology}

\subsection{Institutions, entrepreneurship, and corruption in Indonesia}

Indonesia displays high level of entrepreneurship despite strong corruption, and low institutional quality. The scarcity of financing opportunities, and a poor level of infrastructures (energy, transportation, telecommunication, etc.), reduce the access to resources. Numerous local (district-level) taxes and regulations fall on firms, partly due to a lack of accountability of local governments to central authorities (Moccero 2008). This is best illustrated by the locally set business permits, such as licenses to start and operate a business, import, invest, use specific equipment, or pollute (Henderson and Kuncoro 2011). In addition, firms must pay levies to operate assets such as an escalator, a water pump, and so forth.

The multiple local regulations complicate and slow further federal bureaucratic procedures. Permission to start a new business requires authorizations from 12 different local and national authorities, and it takes 151 days, compared to on average only 54 days in East Asian and Pacific countries, and 20 days in OECD countries (Djankov et al. 2006).

In spite of these institutionally rooted business impediments, Indonesia has experienced a rather dynamic firm entry into the formal sector (Vial 2008). In this context, companies engage in evasive entrepreneurial activities to support or facilitate business. Pervasive petty corruption is indeed widespread at the central and local levels (Aswicahyono et al. 2010). A survey conducted by Transparency International Indonesia (2009) on Indonesian business people shows that one of their four main motives for paying bribes is to obtain business permits. Firms also pay bribes to reduce their taxes, for public procurement proceedings, to get the authorization to buy land or build a new plant, shorten the duration of inspections by bureaucrats, or avoid that such inspections result in new "windfall" levies (Henderson and Kuncoro 2011). Corruption is illegal in Indonesia. Despite regulations, and in the context of the democratization and decentralization since 1998, corruption has declined in some areas, but it remains strong and pervasive in others (Henderson and Kuncoro 2011).

\subsection{Empirical model}

The mediation model is depicted on Fig. 1. Arrow (a) characterizes entrepreneurs' incentive to allocate part of their talent and resources to evasive activities (mediator) to compensate for deficient institutional quality. There is a negative causality: when institutional quality decreases, evasive activities increase. Arrow (b) represents the positive effect of the so-induced evasive activities on conforming activities (dependent variable). The product of the two relations (a) and (b) is the mediation (or indirect effect) of institutional quality on conforming activities (through evasive activities). 


\section{Figure 1 Mediation model}

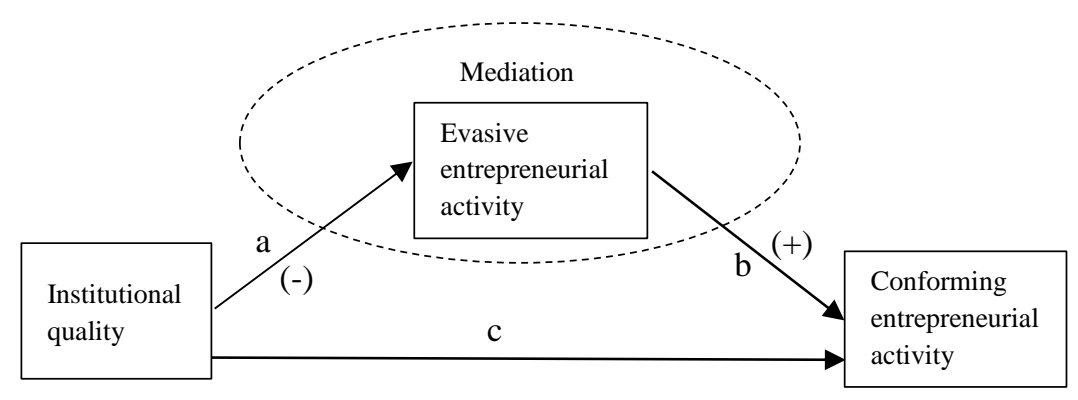

By definition, the mediator is conditioned by the independent variable (institutional quality) and is thus endogenous. We acknowledge that the endogeneity of evasive activities is more complex than accounted for in our central hypothesis. It may also be due to a reverse causality between conforming and evasive activities. Indeed, corruption is often initiated by predatory bureaucrats who manipulate taxes, regulations, and administrative procedures, only for the purpose of extorting briberies (Henderson and Kuncoro 2011). In such situations, conforming activities in ventures are the starting point, incentivizing corrupt bureaucrats and thus inducing evasive activities. Although not the core focus of our theoretical framework, this dimension of endogeneity is controlled for in the empirical part.

\subsection{Data description}

We combine variables from two databases for the period 2000-2009: Statistik Industri (SI) and the Indonesia Family Life Survey (IFLS). SI is a census of registered Indonesian industrial plants with, on average, 20,000 plants each year. The data originate from an annual survey covering all establishments over 20 employees and detailed plant characteristics. Some establishments surveyed could in theory belong to the same firm, but as this effect amounts to less than 5\% of the sample (Narjoko and Hill 2007), we can reasonably treat new ventures as stand-alone firms.

We examine panel data in 371 five-digit subsectors, located in the 430 districts of Indonesia. ${ }^{2}$ Because all industrial subsectors are not present every year and in every administrative district, computing relevant variables at this level of aggregation results in an unbalanced panel of 65,822 fivedigit subsector-district-year observations.

The IFLS (Strauss et al. 2004) is a sociodemographic survey accounting for $83 \%$ of the Indonesian population and collected in five waves (we use the waves 2000 and 2007). It also provides local leaders' (business persons, teachers, health professionals, etc.) perception of the institutional context, including the availability and quality of administrative services, infrastructures, governance, and informal institutions. Data are available at the community level and aggregated at the district level.

\footnotetext{
${ }^{2}$ Five-digit subsectors follow the ISIC classification. The country is administratively divided into provinces, each divided into districts, which are themselves groups of communities.
} 
Merging these two data sets eliminates observations from the SI due to the IFLS' narrower coverage in terms of districts, and we remove five-digit subsector-districts presenting only 1 year of observation. The final data set consists of an unbalanced panel of 33,202 observations (5,866 five-digit subsectordistricts, with on average 5.66 years of observation) over the period 2000-2009, covering 12,053 newly registered firms, in 321 five-digit subsectors and 147 administrative districts. It represents on average 0.363 newly registered firms per subsector-district-year, with a minimum of 0 and a maximum of 323 .

\subsection{Variables}

Variables from SI are observed annually from 2000 to 2009. Because the IFLS variables are only observed in 2000 and 2007, the 2000 values are also used for the years 2001, 2002, 2003, and 2004, and the 2007 values are also used for the years 2005, 2006, 2008, and 2009. This is justified because the relevant institutional variables are not likely to vary rapidly over time (Miguel et al. 2005).

The three key variables of our theoretical framework and hypothesis-conforming and evasive entrepreneurial activities and institutional quality-are unobserved, which requires the use of proxies and indices.

\subsubsection{Dependent variable}

Our dependent variable Entrepreneurship is an indicator of new business density computed from the SI. It is the number of newly registered ventures normalized by the number of paid and unpaid workersthe local working force-in thousands, in each five-digit subsector-district. Our measure of entrepreneurship encompasses a conforming behavior, as the declaration and registration of a new venture is a compliance with legal standards. However, we acknowledge that this indicator can not reflect all conforming entrepreneurial activities, as the legal registration does not alone reveal to what extent a firm will conform with all subsequent legal requirements (e.g., revenue declaration, tax payment, labor and environmental regulations) during the early stages of its development. This leads us to consider Entrepreneurship as our dependent variable, assuming that newly registered firms may undertake evasive entrepreneurial activities, but as a secondary and distinct behavior.

A firm is counted as a new registered venture when its unique identifying number appears for the first time in the SI. Because the data cover only firms with 20 employees or more, a firm appearing in the data set can either be a newly registered firm or an already existing one that has grown over the 20employees threshold. Using the SI over the period 1975-1997, Vial (2008) analyzes the discrepancy between a firm's date of birth and entry in the data set and finds that $50 \%$ of firms display a discrepancy of a maximum of 1 year (median), with an average of 6 years. ${ }^{3}$ The appearance of firms that are older than 1 year in the SI represents a minority of registered entries with a lag and a majority of transitions from unregistered to registered. Indeed, operating as unregistered "should be considered as a stage in

\footnotetext{
${ }^{3}$ Missing data for Firm date of birth prevented us from reproducing a similar analysis for 2000-2009.
} 
the journey of a firm in a developing economy, with transition to the formalized economy and growth as potentially the next stage" (Nguyen et al. 2014: 575). The actual number of registered entries might be underestimated, because some firms may enter with fewer than 20 employees and exit before reaching this threshold. This number, however, is likely to be low, because the majority of micro and small firms belong to the unregistered sector. Entry in the data set therefore generally represents a good lowerbound proxy for registered firm entry with a lag.

\subsubsection{Mediating variable}

We use petty corruption as a proxy of evasive entrepreneurial activities, and we measure it with firms' self-reporting of 'gifts, charities and donations,' stated in the 'other expenses' section of the SI survey. These payments are bribes usually made through charity foundations, the yayasans. They operate in the social, religious, educational, and humanitarian areas, and collect the "gifts" on behalf of, and use them to finance, companies controlled by the corrupt elite. This variable has been used as a proxy for firmlevel corruption (Behrman and Deolalikar 1989; Vial and Hanoteau 2010) and is considered reliable because the SI survey is anonymous and firms are tracked only through their identity number. Such a measure captures directly and isolates part of the evasive entrepreneurial activities that are carried out by registered firms, which are otherwise primarily engaged in conforming activities. ${ }^{4}$ For consistency with the measure of entrepreneurship, we compute the log of the sum of firms' corruption payments in each five-digit subsector-district.

\subsubsection{Causal variables}

Following entrepreneurs' answers to the question about the main local barriers to their activity (Sala-iMartín and Schwab 2016), we consider six different measures of institutional quality covering different regulative and resource-allocative institutions. They are formal (administrative service quality, access to transportation, indirect tax rate, and formal finance cost) or informal (access to informal finance and ethnic homogeneity).

We use the quality of administrative procedures to capture the efficiency of local bureaucracy (Vial 2011). For this, we measure administrative service quality based on local leaders' perception of the quality of identity cards delivered by the local administration. Among infrastructures, poor access to transportation is quoted as the most detrimental by entrepreneurs and business persons. This is obviously related to the geography of the country. This leads us to measure the quality of access to transportation based on local leaders' perception of the quality of provision of transportation services in their area. Both variables are from IFLS, and ordered ranging from 1 (high quality) to 4 (low quality). They are recoded from 1 (low quality) to 4 (high quality) for a more intuitive interpretation, and averaged at the district level.

\footnotetext{
${ }^{4}$ We calculate that about $25 \%$ of firms report zero bribe, and the share over value added is on average $0.26 \%$.
} 
In Indonesia, local officials have a discretionary power on the setting of indirect taxes, and they use it to extort bribes (Henderson and Kuncoro 2011). This leads us to consider indirect tax rate in order to account for the effect of excessive tax. In the SI, indirect taxes include sales taxes, establishment licenses, building and land taxes, motor vehicle taxes, import duties, custom fees, etc. We compute respectively the sum of firms' indirect taxes (A) and value added (B), at the five-digit subsector level. Indirect tax rate is computed as the ratio $\mathrm{A} / \mathrm{B}$.

Giannetti and Ongena (2009) evidence that in emerging countries, the cost of debt, measured at the firm-level as the ratio between interest expenses over debt, reveals the conditions of access to external financing, and that this is especially true for newly created firms. From SI, we first compute respectively, the sum of firms' interest expenses (A) and debt contracted domestically for investment financing (B) at the five-digit subsector level. The cost of debt is computed as the ratio $\mathrm{A} / \mathrm{B}$, and we interpret a higher value of this ratio as a higher formal finance cost.

In Indonesia, the main forms of informal finance are "rotating credit associations" (arisan) (Miguel et al. 2005). From IFLS, we measure the access to informal finance based on household member participation in an arisan. We compute it as the percentage of the population, at the district level, that has participated in an arisan during the last 12 months.

Because ethnic heterogeneity is associated with lower levels of trust, it has a negative impact on entrepreneurship (Churchill 2017). From IFLS, we compute a district-level Herfindahl-based index of ethnic fractionalization and invert its sign to obtain a measure of ethnic homogeneity (Churchill 2017) ranging from -1 to 0 (high to low ethnic fractionalization). To verify the reliability of this measure of trust, we regress an alternative measure of trust perception on ethnic homogeneity using OLS for the year 2007. ${ }^{5}$ The estimated parameter (not presented here), positive and significant, confirms that a higher level of ethnic homogeneity is associated with a higher level of trust at the local level.

To account for the influence and capture different aspects of all six institutional quality measures simultaneously, we construct a multidimensional index using the principal component analysis (PCA) method. For consistency, we respectively recode the formal finance cost and indirect tax rate variables as the ratios (1/formal finance cost) and (1/indirect tax rate), so that a higher value of the PCA index indicates a higher institutional quality for all components. Because different firms are not affected by the same type of institution in a similar manner, using a multidimensional index enables testing for the overall quality of institutions while accounting for firms' heterogeneity and represents a strong robustness test for our model.

\subsubsection{Control variables}

\footnotetext{
${ }^{5}$ This measure of trust is the response to the statement "I trust people with the same ethnicity as mine more", and we use the district-level average. Unfortunately, we cannot use this variable, as it is only available for 2007.
} 
We select control variables from the literature. Individual income has a prominent yet debated impact on entrepreneurship. A higher income may raise the opportunity cost to engage in entrepreneurship, but it is also associated with higher human capital and a transformation of the local economy's structure toward the service sector (Verheul et al. 2002), fostering entrepreneurship. The effect of our individual income measure from IFLS - the district level average of wages in the private sector (in log)—on entrepreneurship is therefore a priori undetermined.

As observed in developing countries (Naudé et al. 2008), and Asia in particular (Carbonara et al. 2019), Education is expected to impact entrepreneurship, although the effect is debated (Quatraro and Vivarelli 2014). We use the average district level of education of household heads (in log).

We include an indicator of the share of urban population. In IFLS, households are categorized using a dummy (urban $=1$; rural $=0$ ). The variable urban area is constructed as the district average of this dummy, a higher value indicating a higher share of urban population. Urban areas generally host a higher population density, which may positively affect entrepreneurship through agglomeration effects and market opportunities (Naudé et al. 2008). Urban wages and land rents, however, become relatively higher, and with an adverse effect on entrepreneurship. The overall effect of location is therefore a priori undetermined (Ghani et al. 2014).

We measure competition as the log of the inverse of the Herfindahl-Hirschman Index at the fivedigit subsector-district level from SI. Although increased competition might be the synonym of wider freedom of entry, it may also act as a 'congesting' factor, deterring entry, in particular if it translates into low margins and less scope for innovation (Naudé et al. 2008).

The density of SMEs in a geographical area is likely to foster entrepreneurship, for instance through the dynamics and supportive effects of small scale industrial clusters and ecosystems (Acs et al. 2017). From SI, we compute an indicator SME density as the number of SMEs - the firms with up to 99 employees - per thousand paid and unpaid workers, at the district level, each year.

Entrepreneurship may be an escape from unemployment, as it is observed empirically in developed countries (Vivarelli and Audretsch 1998), and although the relationship may be non-linear (Storey 1991). Studies of the effect of unemployment on entrepreneurship in developing countries are seldom, and with mixed evidences (Quatraro and Vivarelli 2014). As data on unemployment are not available at the district level for Indonesia, we can not include this control variable, and we acknowledge that this may be a limit. This is nonetheless partly compensated as we run panel regressions with a fixed-effect specification that permits to control for non-observable factors such as district-level of unemployment.

Table 1 provides the descriptive statistics and correlation matrix. It confirms the variance of the main variables (entrepreneurship, evasive entrepreneurial activities, institutional quality) across administrative districts and industrial subsectors in Indonesia. Entrepreneurship is correlated with evasive entrepreneurial activities, whereas all the measures of institutional quality (the PCA index and its six components) correlate with evasive entrepreneurial activities. None of them, except access to informal finance, significantly correlate with entrepreneurship. The five control variables exhibit some 
correlation with each other (wage and urban area are in particular correlated with education) and with the institutional quality $(I Q)$ variables (with the PCA index in particular). We therefore address the issue of potential multicollinearity at the end of the Results section.

\subsection{Estimation method}

We test the relation between $I Q$ and entrepreneurship $(E)$ in a district and a subsector during a year, and as mediated by evasive entrepreneurial activities (EEA). In the mediation analysis (Baron and Kenny 1986), estimates are consistent if errors are non-correlated. We suspect that some unobservable factors, such as the predatory behavior of corrupt bureaucrats manipulating rules and regulations to extort bribes (Henderson and Kuncoro 2011), would explain indirectly $E$ and directly EEA, thus introducing an omitted variable bias. This suggests the endogeneity of EEA, which is confirmed by Hausman tests (Tables 2 and 3), justifying a mediation analysis. Solving the issue requires the use of 2SLS regressions in which the mediator $E E A$ is instrumented. In the first stage, EEA is regressed on the main causal 
Table 1 Descriptive statistics and correlation matrix

\begin{tabular}{|c|c|c|c|c|c|c|c|c|c|c|c|c|c|c|c|c|c|}
\hline & & 1 & 2 & 3 & 4 & 5 & 6 & 7 & 8 & 9 & 10 & 11 & 12 & 13 & 14 & 15 & 16 \\
\hline 1 & Entrepreneurship (E) & 1.00 & & & & & & & & & & & & & & & \\
\hline 2 & Evasive ent. activity (EEA, log) & $-0.077^{*}$ & 1.00 & & & & & & & & & & & & & & \\
\hline 3 & Indirect tax rate & -0.004 & $0.022 *$ & 1.00 & & & & & & & & & & & & & \\
\hline 4 & Formal finance cost & -0.007 & $0.034 *$ & -0.000 & 1.00 & & & & & & & & & & & & \\
\hline 5 & Administrative service quality & -0.002 & $0.015^{*}$ & 0.002 & -0.006 & 1.00 & & & & & & & & & & & \\
\hline 6 & Acces to transportation & -0.007 & $-0.021 *$ & 0.004 & $-0.014 *$ & $0.539^{*}$ & 1.00 & & & & & & & & & & \\
\hline 7 & Access to informal finance & $-0.031 *$ & $-0.176^{*}$ & $0.011 *$ & $0.011 *$ & 0.008 & $0.195^{*}$ & 1.00 & & & & & & & & & \\
\hline 8 & Ethnic homogeneity & $0.023^{*}$ & $-0.165^{*}$ & $-0.019^{*}$ & -0.004 & 0.004 & $0.032 *$ & $0.184 *$ & 1.00 & & & & & & & & \\
\hline 9 & Index (PCA) & -0.006 & $-0.018^{*}$ & 0.003 & $-0.011^{*}$ & $0.869^{*}$ & $0.882 *$ & $0.174 *$ & $0.060^{*}$ & 1.00 & & & & & & & \\
\hline 10 & Competition (log) & $0.032 *$ & $0.197 *$ & -0.006 & 0.005 & $-0.044 *$ & -0.010 & 0.009 & $0.025^{*}$ & $-0.029 *$ & 1.00 & & & & & & \\
\hline 11 & Education $(\log )$ & $-0.041 *$ & $0.106 *$ & 0.005 & 0.008 & $0.232^{*}$ & $0.352 *$ & $0.074 *$ & $-0.298^{*}$ & $0.325^{*}$ & $-0.029 *$ & 1.00 & & & & & \\
\hline 12 & Wages $(\log )$ & 0.007 & $0.273 *$ & 0.001 & -0.000 & $0.150^{*}$ & 0.007 & $-0.568^{*}$ & $-0.386^{*}$ & $0.047^{*}$ & $-0.025 *$ & $0.496^{*}$ & 1.00 & & & & \\
\hline 13 & Urban area & -0.006 & -0.011 & 0.000 & $-0.017^{*}$ & $0.121^{*}$ & $0.412 *$ & $0.082 *$ & $-0.135^{*}$ & $0.302 *$ & -0.007 & $0.484 *$ & $0.165^{*}$ & 1.00 & & & \\
\hline 14 & SME density & $0.092^{*}$ & $-0.228^{*}$ & $-0.011^{*}$ & $-0.021 *$ & $-0.070^{*}$ & $-0.070^{*}$ & $-0.018^{*}$ & $0.238^{*}$ & $-0.073^{*}$ & $0.078^{*}$ & $-0.186^{*}$ & $-0.196^{*}$ & $0.078^{*}$ & 1.00 & & \\
\hline 15 & District average of EEA (log) & -0.050 & $0.344 *$ & $0.014 *$ & $0.012 *$ & $-0.025^{*}$ & $-0.011^{*}$ & $-0.292^{*}$ & $-0.318^{*}$ & $-0.045^{*}$ & 0.001 & $0.170^{*}$ & $0.471^{*}$ & -0.006 & $-0.552 *$ & 1.00 & \\
\hline \multirow[t]{6}{*}{16} & Interaction term & -0.004 & $-0.024 *$ & 0.003 & $-0.012 *$ & $0.861 *$ & $0.878^{*}$ & $0.173^{*}$ & $0.064 *$ & $0.993 *$ & $-0.027 *$ & $0.326^{*}$ & $0.039^{*}$ & $0.309^{*}$ & $-0.059^{*}$ & $-0.066^{*}$ & 1.00 \\
\hline & mean & 0.725 & 10.96 & 0.045 & 3.35 & 3.88 & 3.52 & 0.401 & -0.274 & 0.090 & 2.727 & 1.97 & 15.53 & 0.604 & 6.53 & 12.74 & -1.45 \\
\hline & $\max$ & 36.57 & 20.42 & 141.55 & 3462 & 4.00 & 4.00 & 0.892 & 0.00 & 8.45 & 321.92 & 3.69 & 16.92 & 1.00 & 50.00 & 17.79 & 13.55 \\
\hline & $\min$ & 0.000 & 2.73 & -0.003 & 0.000 & 2.00 & 1.00 & 0.000 & -0.963 & -0.661 & 1.00 & 0.246 & 12.79 & 0.000 & 0.000 & 4.31 & -95.51 \\
\hline & $\mathrm{sd}$ & 3.038 & 2.17 & 1.24 & 80.76 & 0.302 & 0.671 & 0.210 & 0.272 & 1.29 & 5.86 & 0.579 & 0.698 & 0.346 & 6.51 & 1.38 & 16.46 \\
\hline & $\mathrm{N}$ & 33202 & 33202 & 33202 & 33202 & 33202 & 33202 & 33202 & 33202 & 33202 & 33202 & 33202 & 33202 & 33202 & 33202 & 33202 & 33202 \\
\hline
\end{tabular}

Note: $* 5 \%$ level of statiscal significance. 
variable $I Q$, the control variables, and two excluded instruments. In a second stage, $E$ is regressed on the fitted values of $E E A$ obtained from the first stage, $I Q$, and the control variables.

To find a good excluded instrument explaining EEA and uncorrelated with the dependent variable $E$, we use the grouped average technique (Fisman and Svensson 2007; Vial and Hanoteau 2010). We assume that there exist uncorrelated district-specific and subsector-specific elements in $E E A$, and we use the district-average of $E E A$ to instrument for five-digit subsector-district level of $E E A$. This is justified as the grouped average of the instrumented variable $E E A$, captures all unobserved sources of variance predicting EEA. Following Fisman and Svensson (2007), we assume that five-digit subsectordistrict evasive activities $e e a_{i j t}$ consist of two elements, one district-specific, and the other particular to the five-digit subsector: $e e a_{i j t}=E E A_{i j t}+E E A_{j t}$. $E E A_{i j t}$ corresponds to bribing payments justified by reasons idiosyncratic to the industry $i$ at time $t$ (e.g. the underlying technology), and $E E A_{j t}$ is the share of bribes explained by factors specific to a particular district, and reflecting bureaucrats' ability to extort bribes. As the district-specific part of bribery is conditioned by the rent-extraction talents and inclinations of bureaucrats (Henderson and Kuncoro 2011), we assume that this component $E E A_{j t}$ is exogenous to the dependent variable entrepreneurship. In addition, we may expect $E E A_{j t}$ to vary across districts, because some bureaucrats may be more effective at extorting bribes than others. This leads us to use $E E A_{j t}$ - the district average of EEA $(\log )$ - in the 2SLS procedure as an excluded instrument along with $I Q$ and the control variables, to generate the fitted values of $E E A$ at the five-digit subsectordistrict level. Table 1 confirms that district average of EEA $(\log )$ is correlated with EEA but not with $E$.

To add a second excluded instrument, we follow Nichols (2007) who recommends using an interaction term between the excluded instrument and one of the exogenous variables, as this is a valid and better strategy than looking for additional, and likely weak, excluded instruments. When there is an exogenous excluded instrument and the first-stage equation of the 2SLS regression is exactly identified (i.e. one excluded instrument for one instrumented variable), there is always a feasible overidentification test using an augmented set of excluded instruments, and including the interaction term previously described (Nichols 2007). We use the interaction between the district average of EEA (log) and the measure of institutional quality.

To test the mediation hypothesis, we use the Sobel (1982) approach. It consists of testing the significance of an indirect (mediated) effect ( $a b$ ) that is the product of two direct effects depicted in Fig. 1 , and estimated using the 2SLS panel regression. In order to test the significance of (ab), we compute the standard error $\underline{z}$ of the indirect effect and the statistics $a b / z$ to be compared to a standard normal distribution (MacKinnon et al. 2007).

We first run our model using the PCA composite index of institutional quality. Second, we run the model alternatively using each of the six distinct measures of institutional quality. This enables the consistency assessment of our hypothesis, thereby submitting our results to a strong robustness and sensitivity test. As some $I Q$ variables are measured from two data points, a limited time variance could 
justify the use of random effect models. To check whether this is appropriate, we conduct Hausman tests for each $I Q$ variable. The results, not shown here, indicate that the fixed effect specification is the most appropriate in all cases. This specification, which is equivalent to including a time invariant dummy for each observation, controls for district-level and subsector-level unobserved characteristics, such as local unemployment level, that could potentially bias the results.

\section{Results}

Tables 2 and 3 exhibit the results of the second and first stages as well as the identification tests. In Table 2, specification (1) presents the full model, and in specifications (2) to (5), covariates are progressively removed to check for potential effects of multicollinearity. In Table 3, specifications (1) to (6) present the results of the model run alternatively for each component of the PCA index.

Table 4 presents the estimates of the direct effects taken from Tables 2 and 3 as well as the calculated indirect effects and Sobel statistics. For specification (1) (the PCA index), the estimated indirect effect $a b=-0.118$ is negative and significant, and the Sobel statistics $(-5.89)$ confirm the significance of the mediation, thus supporting our central hypothesis. A higher level of $E E A$-induced by a poorer institutional quality (the direct effect $\mathrm{a}=-0.222$ is negative) - explains a higher level of $E$ (the direct effect $\mathrm{b}=0.534$ is positive). Entrepreneurs use $E E A$ - combined with $E$ - to compensate for the effect of low $I Q$ and thereby ensure their conforming objectives. The estimates of specifications (2) to (5) in Table 2 indicate that the mediation effect remains similar to the one estimated for specification (1), showing that any potential multicollinearity does not affect the results.

The specifications (2) to (7) in Table 4 present the results when we consider each single indicator of $I Q$ separately. The indirect effect (ab) and the Sobel statistics are always significant, except for access to informal finance, and with the expected sign, thus also supporting our main assumption in these cases.

The second-stage results using the PCA index (Table 4, specification 1) also reveal the direct effect (c) of $I Q$ on $E$ when controlling for $E E A$. The estimate of (c) is either non-significant, or significant as in the case of cost of formal finance (-0.0003). The indirect effect (ab) and the direct effect (c) are of opposite signs (Table 4 (1)), and this reveals an inconsistent mediation (MacKinnon et al. 2007).

As an alternative to the Sobel (1982) test, and for a robustness check, we also follow the Baron and Kenny (1986) approach. In the presence of an inconsistent mediation, it is enough to evidence that the direct effects (a) and (b) are significant, which is the case with all the $I Q$ indicators, except formal finance cost, administrative services quality, and access to informal finance, as shown in Table 4.

The identification tests (Tables 2 and 3) reveal that the weak identification, under-identification, and over-identification restrictions are broadly satisfied, except for the over-identification test (Hansen$\mathrm{J}$ statistics) in the regressions on the PCA index, administrative service quality, access to transportation, and access to informal finance (Table 3). For these cases, following Nichols (2007), we replace the excluded instrument 'interaction term' by the square of the log of the district average of EEA (the other excluded instrument). The main results—not reported here-remain similar: the Hansen-J statistics are 
improved and the over-identifying restriction is met, confirming the robustness of the results. The joint significance of endogenous regressors and the orthogonality condition (Anderson-Rubin Wald Fstatistic) are always satisfied, supporting the validity of the excluded instruments and the procedure.

Table 2 Panel data instrumental variable (2SLS) regressions

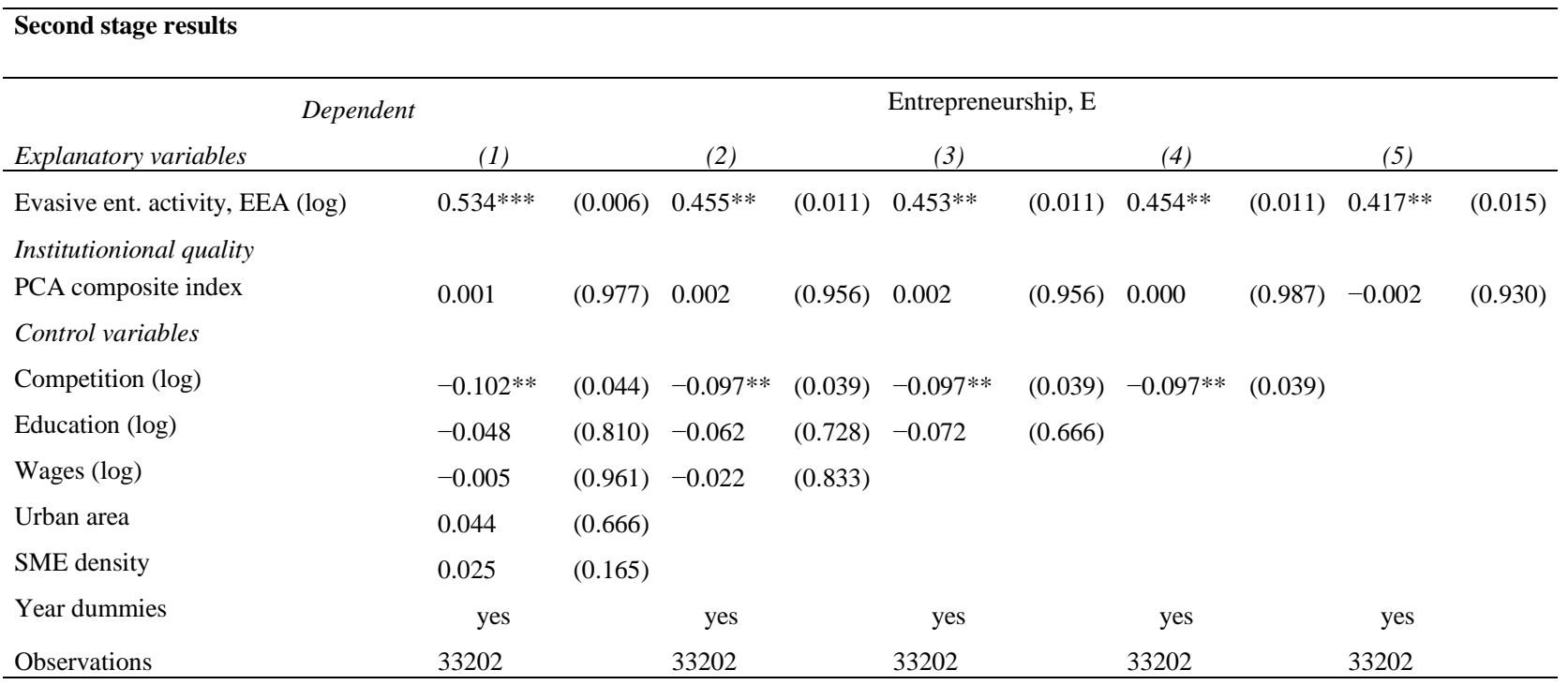

First stage results.

Explanatory variables

\begin{tabular}{|c|c|c|c|c|c|c|c|c|c|c|}
\hline Index PCA & $-0.222 * * *$ & $(0.005)$ & $-0.198 * *$ & $(0.011)$ & $-0.196 * * *$ & $(0.010)$ & $-0.191 * *$ & $(0.013)$ & $-0.185^{* *}$ & $(0.017)$ \\
\hline \multicolumn{11}{|l|}{ Control variables } \\
\hline Competition (log) & $0.054^{* *}$ & $(0.020)$ & $0.055 * *$ & $(0.020)$ & $0.055 * *$ & $(0.020)$ & $0.055^{* *}$ & $(0.020)$ & & \\
\hline Education (log) & 0.076 & $(0.564)$ & 0.165 & $(0.180)$ & 0.173 & $(0.137)$ & & & & \\
\hline Wages (log) & -0.001 & $(0.992)$ & 0.016 & $(0.820)$ & & & & & & \\
\hline Urban area & $-0.153 * *$ & $(0.014)$ & & & & & & & & \\
\hline SME density & 0.005 & $(0.381)$ & & & & & & & & \\
\hline Year dummies & yes & & yes & & yes & & yes & & yes & \\
\hline \multicolumn{11}{|l|}{ Excluded instruments } \\
\hline district average EEA (log) & $0.208 * * *$ & $(0.000)$ & $0.204 * * *$ & $(0.000)$ & $0.204 * * *$ & $(0.000)$ & $0.204 * * *$ & $(0.000)$ & $0.208 * * *$ & $(0.000)$ \\
\hline interaction term & $0.020 * * *$ & $(0.003)$ & $0.017 * * *$ & $(0.008)$ & $0.017 * * *$ & $(0.007)$ & $0.017 * * *$ & $(0.007)$ & $0.016^{* * *}$ & $(0.009)$ \\
\hline \multicolumn{11}{|l|}{ Identification tests } \\
\hline $\begin{array}{l}\text { Kleibergen-Paap Wald } F \text {-statistic } \\
\text { (weak identification test of the } \\
\text { excluded instruments) }\end{array}$ & 67.35 & $(0.000)$ & 62.11 & $(0.000)$ & 63.12 & $(0.000)$ & 63.06 & $(0.000)$ & 63.22 & $(0.000)$ \\
\hline $\begin{array}{l}\text { Anderson-Rubin Wald F-statistic } \\
\text { (test of joint significance of } \\
\text { endogenous regressors) }\end{array}$ & 4.81 & $(0.009)$ & 4.00 & $(0.019)$ & 3.91 & $(0.021)$ & 3.92 & $(0.021)$ & 3.55 & $(0.030)$ \\
\hline $\begin{array}{l}\text { Hansen } \mathbf{J} \text { statistics (test of } \\
\text { overidentifying restrictions) }\end{array}$ & 0.788 & $(0.375)$ & 1.123 & $(0.289)$ & 1.140 & $(0.283)$ & 1.146 & $(0.284)$ & 1.29 & $(0.256)$ \\
\hline $\begin{array}{l}\text { Kleibergen-Paap RK LM statistic } \\
\text { (underidentification test) }\end{array}$ & 47.42 & $(0.000)$ & 46.30 & $(0.000)$ & 46.72 & $(0.000)$ & 46.67 & $(0.000)$ & 46.50 & $(0.000)$ \\
\hline Haussman test of endogeneity & 11.04 & $(0.001)$ & 9.01 & $(0.003)$ & 8.77 & $(0.003)$ & 8.79 & $(0.003)$ & 8.42 & $(0.004)$ \\
\hline
\end{tabular}


Table 3 Panel data instrumental variable (2SLS) regressions

\begin{tabular}{|c|c|c|c|c|c|c|}
\hline \multicolumn{7}{|l|}{ Second stage results } \\
\hline \multirow{2}{*}{$\begin{array}{l}\text { Dependent } \\
\text { Explanatory variables }\end{array}$} & \multicolumn{6}{|c|}{ Entrepreneurship, E } \\
\hline & (1) & (2) & (3) & (4) & $(5)$ & (6) \\
\hline EEA $(\log )$ & $0.505^{* * *}(0.005)$ & $0.506^{* * * *}(0.005)$ & $0.516^{* * *}(0.004)$ & $0.526 * * *(0.006)$ & $0.552^{* * * *}(0.003)$ & $0.500 * * *(0.006)$ \\
\hline \multicolumn{7}{|l|}{ Institutional quality } \\
\hline Indirect tax rate & $-0.006(0.188)$ & & & & & \\
\hline Formal finance cost & & $-0.0003 *(0.098)$ & & & & \\
\hline Admin. service quality & & & $-0.0004(0.997)$ & & & \\
\hline Access to transp. & & & & $0.006(0.941)$ & & \\
\hline Access to informal fi. & & & & & $0.295(0.383)$ & \\
\hline Ethnic homogeneity & & & & & & $-0.150(0.667)$ \\
\hline \multicolumn{7}{|l|}{ Control variables } \\
\hline Competition (log) & $-0.101 * *(0.045)$ & $-0.101^{* *}(0.045)$ & $-0.101 * *(0.045)$ & $-0.102 * *(0.044)$ & $-0.103 * *(0.042)$ & $-0.100^{* *}(0.045)$ \\
\hline Education $(\log )$ & $-0.045(0.812)$ & $-0.047(0.801)$ & $-0.045(0.819)$ & $-0.049(0.806)$ & $-0.059(0.755)$ & $-0.049(0.791)$ \\
\hline Wages $(\log )$ & $-0.004(0.973)$ & $-0.002(0.986)$ & $-0.004(0.969)$ & $-0.005(0.964)$ & $0.001(0.994)$ & $0.001(0.991)$ \\
\hline Urban area & $0.040(0.689)$ & $0.039(0.698)$ & $0.042(0.674)$ & $0.041(0.703)$ & $0.053(0.607)$ & $0.055(0.611)$ \\
\hline SME density & $0.025(0.167)$ & $0.025(0.170)$ & $0.025(0.167)$ & $0.025(0.165)$ & $0.026(0.155)$ & $0.025(0.172)$ \\
\hline Year dummies & yes & yes & yes & yes & yes & yes \\
\hline Observations & 33202 & 33202 & 33202 & 33202 & 33202 & 33202 \\
\hline
\end{tabular}

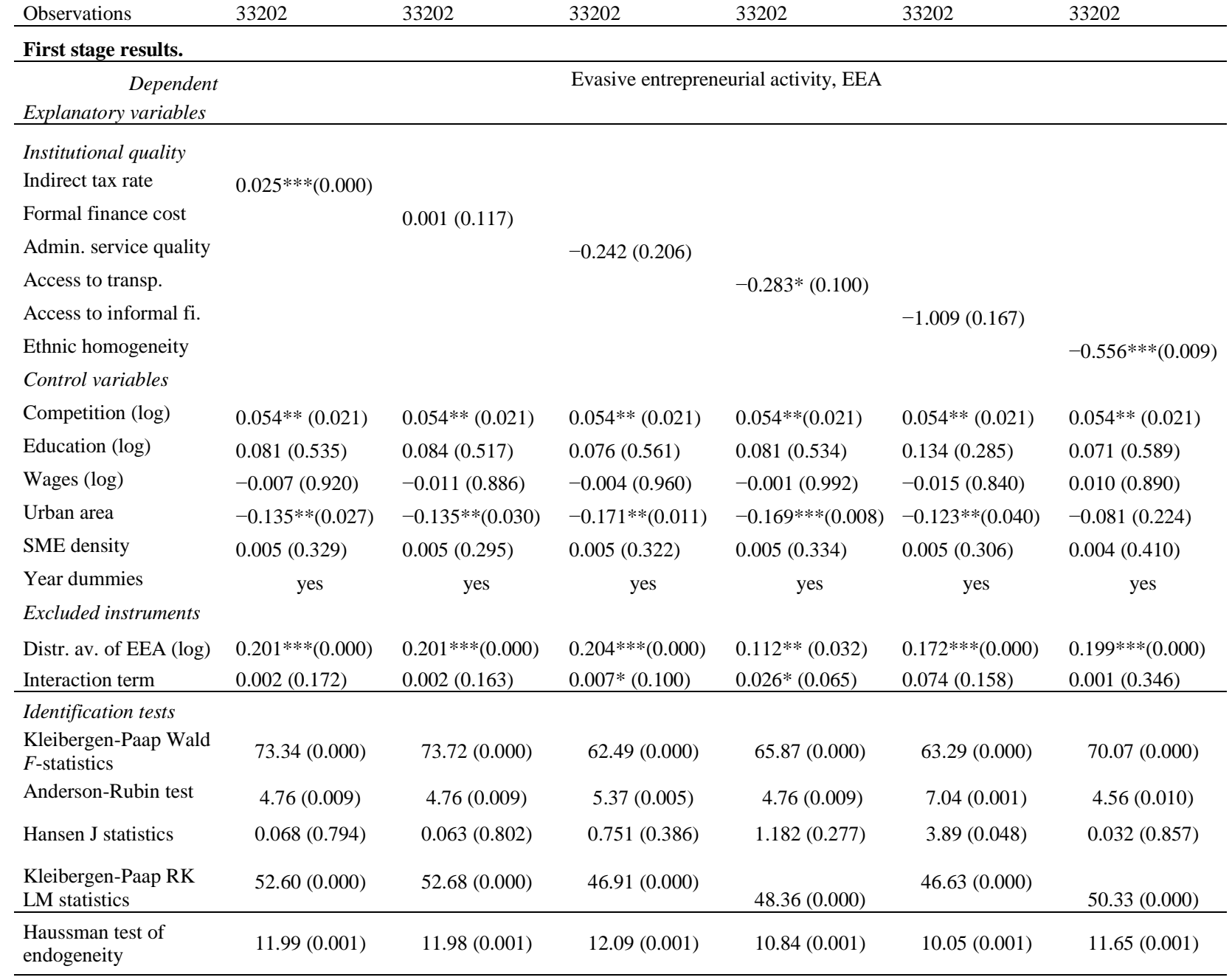

Notes: $*, * * * * * 10 \%, 5 \%$ and $1 \%$ levels of statistical significance. All panel regressions are fixed effect. Standard errors are cluster robust. Pvalues in parentheses. 
Table 4 Mediating effect of evasive entrepreneurial activity (EEA) on the relationship between institutional quality (IQ) and entrepreneurship (E)

\begin{tabular}{|c|c|c|c|c|c|c|c|c|c|c|c|c|c|c|}
\hline & \multirow{2}{*}{\multicolumn{2}{|c|}{ PCA index }} & \multicolumn{2}{|l|}{ (2) } & \multicolumn{2}{|c|}{ (3) } & \multicolumn{2}{|l|}{ (4) } & \multicolumn{2}{|l|}{ (5) } & \multicolumn{2}{|l|}{ (6) } & \multicolumn{2}{|l|}{ (7) } \\
\hline & & & Indirect to & s rate & Formal fina & e cost & $\begin{array}{l}\text { Administr } \\
\text { services qu }\end{array}$ & $\begin{array}{l}\text { tive } \\
\text { ality }\end{array}$ & $\begin{array}{r}\text { Access } \\
\text { transport }\end{array}$ & to & $\begin{array}{l}\text { Access to in } \\
\text { finane }\end{array}$ & formal & $\begin{array}{r}\text { Ethnic } \\
\text { homogen }\end{array}$ & eity \\
\hline & coefficient & SE & coefficient & SE & coefficient & SE & coefficient & SE & coefficient & SE & coefficient & SE & coefficient & SE \\
\hline \multicolumn{15}{|l|}{ Direct effects } \\
\hline c: IQ --> E & -0.001 & 0.030 & -0.006 & 0.005 & $-0.0003^{*}$ & 0.0002 & -0.000 & 0.110 & -0.006 & 0.076 & 0.296 & 0.339 & -0.150 & 0.349 \\
\hline a: IQ --> EEA & $-0.222 * * *$ & 0.079 & $0.025 * * *$ & 0.004 & 0.001 & 0.0004 & -0.242 & 0.191 & $-0.283^{*}$ & 0.176 & -1.010 & 0.730 & $-0.556 * * *$ & 0.212 \\
\hline b: EEA --> E & $0.534 * * *$ & 0.193 & $0.505 * * *$ & 0.180 & $0.506 * * *$ & 0.180 & $0.516 * * *$ & 0.180 & $0.526 * * *$ & 0.180 & $0.552 * * *$ & 0.183 & $0.500 * * *$ & 0.183 \\
\hline \multicolumn{15}{|l|}{ Indirect effect ${ }^{+}$} \\
\hline ab: IQ --> EEA --> E & $-0.118 * * *$ & 0.062 & $0.013 * * *$ & 0.005 & $0.0003 * * *$ & 0.0002 & $-0.125 * * *$ & 0.113 & $-0.149 * * *$ & 0.112 & -0.557 & 0.463 & $-0.278 * * *$ & 0.152 \\
\hline Sobel statistics & $-5.89 * *$ & & $-73.43 * *$ & & $-1672.84 * *$ & & $-3.22 * *$ & & $-3.25^{* *}$ & & -0.787 & & $-2.40 * *$ & \\
\hline
\end{tabular}

Notes: *,*****10\%,5\%, and 1\% levels of statistical significance. PCA = Principal Component Analysis. SE = standard error.

$c$ and $b$ are from the second stage (tables 2 and 3); $a$ is from the first stage (tables 2 and 3).

tThe standard error $z$ of the indirect effect ab is computed as the formula $\quad z=\sqrt{\left(a^{2} s_{b}^{2}+b^{2} s_{a}^{2}+s_{a}^{2} s_{b}^{2}\right)} \quad$ and the Sobel statistics is the ratio ab/z.

Sobel statistics larger than 1.96 in absolute value is significant at the 0.05 level 
The second-stage results exhibit the estimated parameters for the control variables (Tables 2 and 3), and their sign meet the expectations formulated in the presentation of variables.

\section{Conclusion}

Building on Baumol's (1990) theory of entrepreneurship's outcomes (productive, unproductive, and destructive) in a framework of failing institutions, we argue that entrepreneurship is characterized by two types of entrepreneurial activities that can both and simultaneously be carried out by a single firm (Douhan and Henrekson 2010). Entrepreneurs either conform with or deviate from the institutional framework to engage in either abiding or evasive activities. We hypothesize that evasive activity (bribing) is undertaken as a second best response to poor institutional quality, and to support the creation of new firms. We test this in the context of Indonesia, using five-digit subsector-district level data on entrepreneurship over the period 2000-2009. Instrumental variable panel regressions enable to test for a mediation model, and thereby unveiling the real effect of local institutional quality on entrepreneurship.

We observe that low institutional quality is detrimental to the entry of new ventures, whereas it fosters firms' bribing, which in turn, supports entry. Our results thus evidence the mediating effect of firms' bribing on the relation between institutional quality and the entry of new firms.

Our approach hence offers new light on corruption, going beyond the classical grease-the-wheel effect (Dreher and Gassebner 2013; Zhou and Peng 2012). In those studies, corruption is treated as an exogenous institutional feature rather than as an endogenous entrepreneurial activity. Corruption requires an interaction between the institutional and the market spheres, a functioning that is conceptualizable when corruption is treated as an endogenous evasive activity, and mediating the relation between institutional quality and new venture creation.

Dutta and Sobel (2016) show that a country's overall level of corruption always harms entrepreneurship because of its negative indirect effect that often outweighs its potential direct positive effect. Our study complements their results because it focuses on the direct beneficial effect of corruption in the context of under-developed institutions, common to numerous developing countries.

This article contributes to the growing literature on entrepreneurship in Southeast Asian emerging economies, as illustrated by Carbonara et al. (2019). Like these authors, we follow an occupational choice approach to study the choice of entrepreneurial activities, underlining in our case to what extent the institutional context can lead a single firm to undertake a mix of different entrepreneurial activities. Our results are in the same vein of those obtained by Tran (2019) in the case of Vietnam and who evidence the detrimental impact of poor local institutional quality on the performance of new ventures.

Our research has policy implications, putting forward the importance of improving local business conditions (tax burden, ease of doing business, and access to resources such as finance and utilities) for supporting the entry of new firms. This has the potential of "killing two birds with one stone", as this would also reduce entrepreneurs' evasive activities (corruption) undertaken as a second-best substitute for poor-quality institutions, thus addressing the corruption problem at the root. 


\section{References}

Acs, Z.J., Stam, E., Audretsch, D.B. \& O’Connor, A. (2017). The lineages of the entrepreneurial ecosystem approach. Small Business Economics, 49(1), 1-10.

Aswicahyono, H., Hill, H., \& Narjoko, D. (2010). Industrialisation after a deep economic crisis: Indonesia. The Journal of Development Studies, 46(6), 1084-1108.

Baron, R. M., \& Kenny, D. A. (1986). The moderator-mediator variable distinction in social psychological research: Conceptual, strategic, and statistical considerations. Journal of Personality and Social Psychology, 51(6), 1173-1182.

Baumol ,W. J. (1990). Entrepreneurship: Productive, unproductive, and destructive. Journal of Political Economy, 98(5), 893-921.

Baumol, W.J. (2010). The micro-theory of innovative entrepreneurship. Princeton, NJ: Princeton University Press.

Behrman, J. R., \& Deolalikar, A. B. (1989). Of the fittest? Duration of survival of manufacturing establishments in a developing country. The Journal of Industrial Economics, 38(2), 215-226.

Belitski, M., Chowdhury, F., \& Desai, S. (2016). Taxes, corruption, and entry. Small Business Economics, 47(1), 201-216.

Carbonara, E., Tran, H.T. \& Santarelli, E. (2019). Determinants of novice, portfolio, and serial entrepreneurship: an occupational choice approach. Small Business Economics, 1-29. Doi: 10.1007/s11187-019-00138-9.

Chowdhury, F. \& Audretsch, D.B. (2014). Institution as looting apparatus: impact of gender equality and institutions on female entrepreneurship. Eurasian Business Review, 4(2), 207-225.

Churchill, S. A. (2017). Fractionalization, entrepreneurship, and the institutional environment for entrepreneurship. Small Business Economics, 48(3), 577-597.

Davidsson, P., \& Wiklund, J. (2001). Levels of analysis in entrepreneurship research: Current research practice and suggestions for the future. Entrepreneurship Theory and Practice, 25(4), 81-100.

de Jong, G., Tu, P. A., \& Van Ees, H. (2012). Which entrepreneurs bribe and what do they get from it? Exploratory evidence from Vietnam. Entrepreneurship Theory and Practice, 36(2), 323-345.

Díez-Esteban, J.M., Farinha, J.B. \& García-Gómez, C.D. (2019). How does national culture affect corporate risk-taking? Eurasian Business Review, 9(1), 49-68.

Djankov, S., La Porta, R., Lopez-de-Silanes, F., \& Shleifer, A. (2002). The regulation of entry. Quarterly Journal of Economics, 117(1), 1-37.

Djankov, S., McLiesh, C. \& Klein, M.U. (2006). Doing Business in 2006: Creating Jobs (Vol. 3). Washington DC: World Bank Publications.

Douhan, R., \& Henrekson, M. (2010). Entrepreneurship and second-best institutions: Going beyond Baumol's typology. Journal of Evolutionary Economics, 20(4), 629-643.

Dreher, A., \& Gassebner, M. (2013). Greasing the wheels? The impact of regulations and corruption on firm entry. Public Choice, 155(3-4), 413-432.

Dutta, A., \& Sobel, R. (2016). Does corruption ever help entrepreneurship? Small Business Economics, 47(1), 179-199.

Elert, N., \& Henrekson, M. (2016). Evasive entrepreneurship. Small Business Economics, 47(1), $95-113$.

Firman, T. (2009). Decentralization reform and local-government proliferation in Indonesia: Towards a fragmentation of regional development. Review of Urban \& Regional Development Studies, 21(2-3), 143-157.

Fisman, R. \& Svensson, J. (2007). Are corruption and taxation really harmful to growth? Firm level evidence. Journal of Development Economics, 83(1), 63-75.

Ghani, E., \& Kerr, W. R., \& O'Connell, S. (2014). Spatial determinants of entrepreneurship in India. Regional Studies, 48(6), 1071-1089.

Giannetti, M., \& Ongena S. (2007). Financial integration and firm performance: Evidence from foreign bank entry in emerging markets. Review of Finance, 13(2), 181-223.

Gohmann, S. F. (2012). Institutions, latent entrepreneurship, and self-employment: An international comparison. Entrepreneurship Theory and Practice, 36(2), 295-321.

Henderson, J. V., \& Kuncoro, A. (2011). Corruption and local democratization in Indonesia: The role of Islamic parties. Journal of Development Economics, 94(2), 164-180.

Kistruck, G. M., Webb, J. M., Sutter, C. J., \& Bailey, A. V. (2015). The double-edged sword of legitimacy in base-of-the-pyramid markets. Journal of Business Venturing, 30(3), 436-451.

MacKinnon, D., Fairchild, A., \& Fritz, M. (2007). Mediation analysis. Annual Review of Psychology, 58, 593614.

Madestam. A. (2014). Informal finance: A theory of moneylenders. Journal of Development Economics, 107, 157174. 
Mauro, P. (1995). Corruption and growth. Quarterly Journal of Economics, 110(3), 681-712.

Méon, P. G., \& Weill, L. (2010). Is corruption an efficient grease? World Development, 38(3), 244-259.

Miguel, E., Gertler, P., \& Levine, D. (2005). Does social capital promote industrialization? Evidence from a rapid industrializer. Review of Economics and Statistics, 87(4), 754-762.

Moccero, D. (2008). Improving the business and investment climate in Indonesia. OECD Working Paper 638.

Murphy, K.M., Shleifer, A., \& Vishny, R.W. (1991). The allocation of talent: Implications for growth. Quarterly Journal of Economics, 106(2), 503-530.

Narjoko, D., \& Hill, H. (2007). Winners and losers during a deep economic crisis: Firm-level evidence from Indonesian manufacturing. Asian Economic Journal, 21(4), 343-368.

Naudé, W., Gries, T., Wood, E., \& Meintjies, A. (2008). Regional determinants of entrepreneurial start-ups in a developing country. Entrepreneurship and Regional Development, 20(2), 111-124.

Nichols, A. (2007). Causal inference with observational data. Stata Journal, 7(4), 507-541.

Nguyen, T., Verreynne, M.-L., \& Steen, J. (2014). Drivers of firm formalization in Vietnam: An attention theory explanation. Entrepreneurship and Regional Development, 26(7-8), 574-593.

Nooteboom, B. (2007). Social capital, institutions and trust. Review of Social Economy, 65(1), $29-53$.

North, D. C. (1990). Institutions, institutional change and economic performance. New York, NY: Cambridge University Press.

Park, S. H., \& Luo, Y. (2001). Guanxi and organizational dynamics: Organizational networking in Chinese firms. Strategic Management Journal, 22(5), 455-477.

Puffer, S., McCarthy, D., \& Boisot, M. (2010). Entrepreneurship in Russia and China: The impact of formal institutional voids. Entrepreneurship Theory and Practice, 34(3), 441-467.

Quatraro, F. \& Vivarelli, M. (2014). Drivers of entrepreneurship and post-entry performance of newborn firms in developing countries. The World Bank Research Observer, 30(2), 277-305.

Sala-i-Martín, X., \& Schwab, K. (Eds.). (2016). Global competitiveness report 2017. Geneva, Switzerland: The World Economic Forum. www.weforum.org/gcr

Sobel, M. E. (1982). Asymptotic confidence intervals for indirect effects in structural equation models. Sociological Methodology, 13, 290-312.

Storey, D.J. (1991). The birth of new firms-does unemployment matter? A review of the evidence. Small business economics, 3(3), 167-178.

Strauss, J., Beegle, K., Sikoki, B., Dwiyanto, A., Herawati, Y., \& Witoelar, F. (2004). The third wave of the Indonesia Family Life Survey (IFLS3): Overview and field report. Santa Monica, CA: RAND.

Tanzi, V. (1998). Corruption around the world: Causes, consequences, scope, and cures. IMF Staff Papers, 45(4), 559-594.

Tonoyan, V., Strohmeyer, R., Habib, M., \& Perlitz, M. (2010). Corruption and entrepreneurship: How formal and informal institutions shape small firm behaviour in transition and mature market economies. Entrepreneurship Theory and Practice, 34(5), 803-832.

Tran, H. T. (2019). Institutional quality and market selection in the transition to market economy. Journal of Business Venturing, 34(5), 1-11.

Transparency International Indonesia. (2009). Indonesia corruption perception index 2008 and bribery index. www.ti.or.id/media/documents/2010/11/09/i/p/ipk-english_final.pdf

Verheul, I., Wennekers, S., Audretsch, D. B., Thurik, R. (2002). An eclectic theory of entrepreneurship: Policies, institutions and culture. In D. B. Audretsch, R. Thurik, I. Verheul, \& S. Wennekers (Eds.),

Entrepreneurship: Determinants and policy in a European-U.S. comparison (pp. 11-82). Norwell, MA: Kluwer Academic Publishers.

Vial, V. (2008). How much does turnover matter? Evidence from Indonesian manufacturing total factor productivity growth, 1975-95. Oxford Development Studies, 36(3), 295-322.

Vial, V. (2011). Micro-entrepreneurship in a hostile environment: Evidence from Indonesia. Bulletin of Indonesian Economic Studies, 47(2), 233-262.

Vial, V., \& Hanoteau, J. (2010). Corruption, manufacturing plant growth and the Asian paradox: Indonesian evidence. World Development, 38(5), 693-705.

Vivarelli, M. \& Audretsch, D. (1998). The link between the entry decision and post-entry performance: evidence from Italy. Industrial and Corporate Change, 7(3), 485-500.

Webb, J. W., Tihanyi, L., Ireland, R. D., \& Sirmon, D. G. (2009). You say illegal, I say legitimate: Entrepreneurship in the informal economy. Academy of Management Review, 34(3), 492-510.

Zhou, J. Q., \& Peng, M. W. (2012). Does bribery help or hurt firm growth around the world? Asia Pacific Journal of Management, 29(4), 907-921. 